\title{
ANALISA KURVA HAZARD PADA KABUPATEN TAMBRAUW DENGAN MENGGUNAKAN BEBERAPA FUNGSI ATENUASI
}

\author{
Lilis Fitri Handayani ${ }^{1)}$, Anang Khoirul Azhar ${ }^{2)}$, Serly Marlina ${ }^{3)}$ \\ ${ }^{1), 2), 3)}$ Program Studi Teknik Sipil, Universitas Muhammadiyah Sorong \\ Email : lilisfitrihandayani1@gmail.com
}

\begin{abstract}
Abstrak
Kabupaten Tambrauw adalah salah satu kabupaten di Provinsi Papua Barat, Indonesia. Pusat pemerintahan berada di Fef. Kabupaten Tambrauw mempunyai luas wilayah 11 $529,19 \mathrm{Km}^{2}$, yang terdiri dari daratan dan lautan. Secara geografis Kabupaten Tambrauw pada sebelah Utara berbatasan dengan Samudera Pasifik, sebelah Selatan berbatasan dengan Kabupaten Sorong Selatan dan sebelah Timur berbatasan dengan Distrik Sidey dan Kabupaten Manokwari. Ada beberapa metode yang dapat digunakan dalam Seismic Hazard Assessment untuk membuat prediksi kejadian gempa di masa yang akan datang (gempa rencana). Pada analisa ini, Seismic Hazard Assessment menggunakan The Line Source Method untuk membuat Hazard curve yang dapat memperkirakan kejadian gempa di Kabupaten Tambrauw. Kurva hazard dibuat menggunakan fungsi atenuasi Esteva (1970), fungsi Atenuasi Hou \& Hu (1991), fungsi Atenuasi Ambraseys (1995) dan fungsi Atenuasi Crouse-Mc Guirre (1996). Hasil analisa menunjukkan besarnya nilai percepatan tanah (ground acceleration) akan semakin mengecil pada jarak atau radius yang semakin jauh. Analisis kurva hazard pada daerah Kabupaten Tambrauw akibat pergeseran lempeng akan menunjukkan nilai terbesar pada saat menggunakan fungsi atenuasi Hou \& Hu (1991) dan analisis kurva hazard pada daerah Kabupaten Tambrauw akibat pergeseran lempeng akan menunjukkan nilai terkecil pada saat menggunakan fungsi atenuasi Crouse-McGuirre (1996), $\mathrm{F}=0$.
\end{abstract}

Kata Kunci : Kurva Hazard, Atenuasi, Kabupaten Tambrauw

\section{Pendahuluan}

Atenuasi getaran tanah (ground motion attenuation) adalah proses atau rumusan yang mana suatu gerakan tanah $\mathrm{Y}$ akibat gempa (percepatan, kecepatan, simpangan) ataupun intensitas gempa akan mengecil pada jarak yang semakin jauh dari sumber gempa, akibat redaman atau penyerapan energi oleh massa batuan atau tanah. Faktor faktor yang mempengaruhi atenuasi yaitu sebagai berikut :

a. Ukuran gempa $\left(\mathrm{M}_{\mathrm{L}}, \mathrm{M}_{\mathrm{S}}, \mathrm{Mb}, \mathrm{M}_{\mathrm{W}}\right)$

Semakin besar magnitudo gempa $M$, maka semakin besar gerakan tanah (percepatan, kecepatan, simpangan) yang beratenuasi.

b. Jarak ke site (jarak episenter, jarak terdekat, jarak hiposenter)

Semakin jauh jarak dari pusat gempa, gerakan tanah semakin kecil. 
c. Mekanisme Sumber gempa :

- Atenuasi Shallow Crustal Earthquake (active dan stable plate continent)

- Atenuasi Subduction Earthquake (interface slip dan intraslab earthquake)

d. Pengaruh kondisi site

Tanah keras dan tanah lunak akan berpengaruh terhadap gerakan tanah.

Ada beberapa metode yang dapat digunakan dalam Seismic Hazard Assessment untuk membuat prediksi kejadian gempa di masa yang akan datang (gempa rencana). Pada analisa ini, Seismic Hazard Assessment menggunakan The Line Source Method untuk membuat Hazard curve yang dapat memperkirakan kejadian gempa di Kabupaten Tambrauw. Rumus Atenuasi yang digunakan adalah Esteva (1970), Atenuasi Hou \& Hu (1991), Atenuasi Ambraseys (1995) dan Atenuasi Croose-Mc Guirre (1996).

\section{Kabupaten Tambrauw}

Kabupaten Tambrauw adalah salah satu kabupaten di Provinsi Papua Barat, Indonesia. Pusat pemerintahan berada di Fef. Kabupaten Tambrauw mempunyai luas wilayah 11.529,19 $\mathrm{Km}^{2}$, yang terdiri dari daratan dan lautan. Secara geografis Kabupaten Tambrauw berbatasan dengan :

$\begin{array}{ll}\text { Utara } & \text { : Samudera Pasifik } \\ \text { Selatan } & \text { : Kabupaten Sorong Selatan } \\ \text { Barat } & \text { : Kabupaten Sorong } \\ \text { Timur } & \text { : Distrik Sidey dan Kabupaten Manokwari }\end{array}$

Tabel 1 Letak Kabupaten Tambrauw

\begin{tabular}{|l|c|c|}
\hline \multicolumn{3}{|c|}{ Koordinat Kabupaten Tambrauw: } \\
\hline Longitude & $132.393810^{\circ}$ & BT \\
\hline Latitude & $-0.782116^{\circ}$ & LU \\
\hline \hline
\end{tabular}

\section{Tujuan}

Pada analisa ini bertujuan untuk membuat Hazard curve yang dapat memperkirakan kejadian gempa di Kabupaten Tambrauw dengan menggunakan beberapa fungsi atenuasi diantaranya : fungsi atenuasi Esteva (1970), fungsi Atenuasi Hou \& Hu (1991), fungsi Atenuasi Ambraseys (1995) dan fungsi Atenuasi Crouse-Mc Guirre (1996).

\section{Menghitung Fungsi Atenuasi}

Fungsi atenuasi perlu diperhitungkan karena kekuatan gempa bumi berpengaruh terhadap jarak dari episenter gempa. Semakin jauh maka kecenderungan kekuatannya menurun, walaupun terdapat beberapa kasus yang berbeda. Tetapi hal ini disebabkan oleh kondisi setempat (local site). Dalam analisa menggunakan fungsi atenuasi yang 
digunakan adalah fungsi Atenuasi Esteva (1970), fungsi Atenuasi Hou \& Hu (1991), fungsi Atenuasi Ambraseys (1995) dan Fungsi Atenuasi Crouse-Mc Guirre (1996).

\section{Fungsi Atenuasi Esteva (1970)}

$\mathrm{Y}=1230 \cdot \mathrm{e}^{0,8 \cdot \mathrm{M}}(\mathrm{R}+25)^{-2}$

Dengan nilai e $=2,71828183$

$$
\begin{aligned}
& \mathrm{M}=5,9 \mathrm{SR} \\
& \mathrm{R}=1-100 \mathrm{Km}
\end{aligned}
$$

\begin{tabular}{|c|c|c|c|c|c|c|c|}
\hline \multicolumn{4}{|c|}{ Esteva, 1970} & \multicolumn{4}{|c|}{$\mathbf{R}$} \\
\hline 1 & 2 & 3 & 4 & 1 & 2 & 3 & 4 \\
\hline 204,09312 & 53,04381 & 23,886245 & 13,524846 & 1 & 26 & 51 & 76 \\
\hline 189,25508 & 51,023281 & 23,269852 & 13,260953 & 2 & 27 & 52 & 77 \\
\hline 175,97825 & 49,116038 & 22,677014 & 13,004708 & 3 & 28 & 53 & 78 \\
\hline 164,05107 & 47,313769 & 22,106546 & 12,75582 & 4 & 29 & 54 & 79 \\
\hline 153,29661 & 45,608909 & 21,557336 & 12,514009 & 5 & 30 & 55 & 80 \\
\hline 143,56603 & 43,994563 & 21,028342 & 12,27901 & 6 & 31 & 56 & 81 \\
\hline 134,73335 & 42,464435 & 20,518583 & 12,050568 & 7 & 32 & 57 & 82 \\
\hline 126,69141 & 41,012768 & 20,027138 & 11,828442 & 8 & 33 & 58 & 83 \\
\hline 119,34857 & 39,634286 & 19,553139 & 11,612402 & 9 & 34 & 59 & 84 \\
\hline 112,62608 & 38,324153 & 19,095772 & 11,402227 & 10 & 35 & 60 & 85 \\
\hline 106,45598 & 37,077923 & 18,654266 & 11,197707 & 11 & 36 & 61 & 86 \\
\hline 100,77937 & 35,891506 & 18,227897 & 10,998641 & 12 & 37 & 62 & 87 \\
\hline 95,54498 & 34,761137 & 17,81598 & 10,804836 & 13 & 38 & 63 & 88 \\
\hline 90,708054 & 33,683338 & 17,41787 & 10,616109 & 14 & 39 & 64 & 89 \\
\hline 86,229344 & 32,6549 & 17,032957 & 10,432284 & 15 & 40 & 65 & 90 \\
\hline 82,074331 & 31,672854 & 16,660663 & 10,253192 & 16 & 41 & 66 & 91 \\
\hline 78,212557 & 30,734451 & 16,300443 & 10,078673 & 17 & 42 & 67 & 92 \\
\hline 74,617064 & 29,837143 & 15,951781 & 9,9085716 & 18 & 43 & 68 & 93 \\
\hline 71,263921 & 28,978566 & 15,614186 & 9,7427407 & 19 & 44 & 69 & 94 \\
\hline 68,131828 & 28,156521 & 15,287197 & 9,5810382 & 20 & 45 & 70 & 95 \\
\hline 65,201773 & 27,368965 & 14,970372 & 9,4233284 & 21 & 46 & 71 & 96 \\
\hline 62,456745 & 26,613995 & 14,663296 & 9,2694807 & 22 & 47 & 72 & 97 \\
\hline 59,881489 & 25,889839 & 14,365572 & 9,1193701 & 23 & 48 & 73 & 98 \\
\hline 57,462287 & 25,194841 & 14,076824 & 8,9728766 & 24 & 49 & 74 & 99 \\
\hline 55,18678 & 24,527458 & 13,796695 & 8,8298849 & 25 & 50 & 75 & 100 \\
\hline
\end{tabular}

Tabel 2 Hitungan Persamaan Atenuasi Esteva (1970)

Berdasarkan data perhitungan analisa di atas maka diperoleh kurva hazard seperti yang terlihat pada Gambar 1 berikut: 


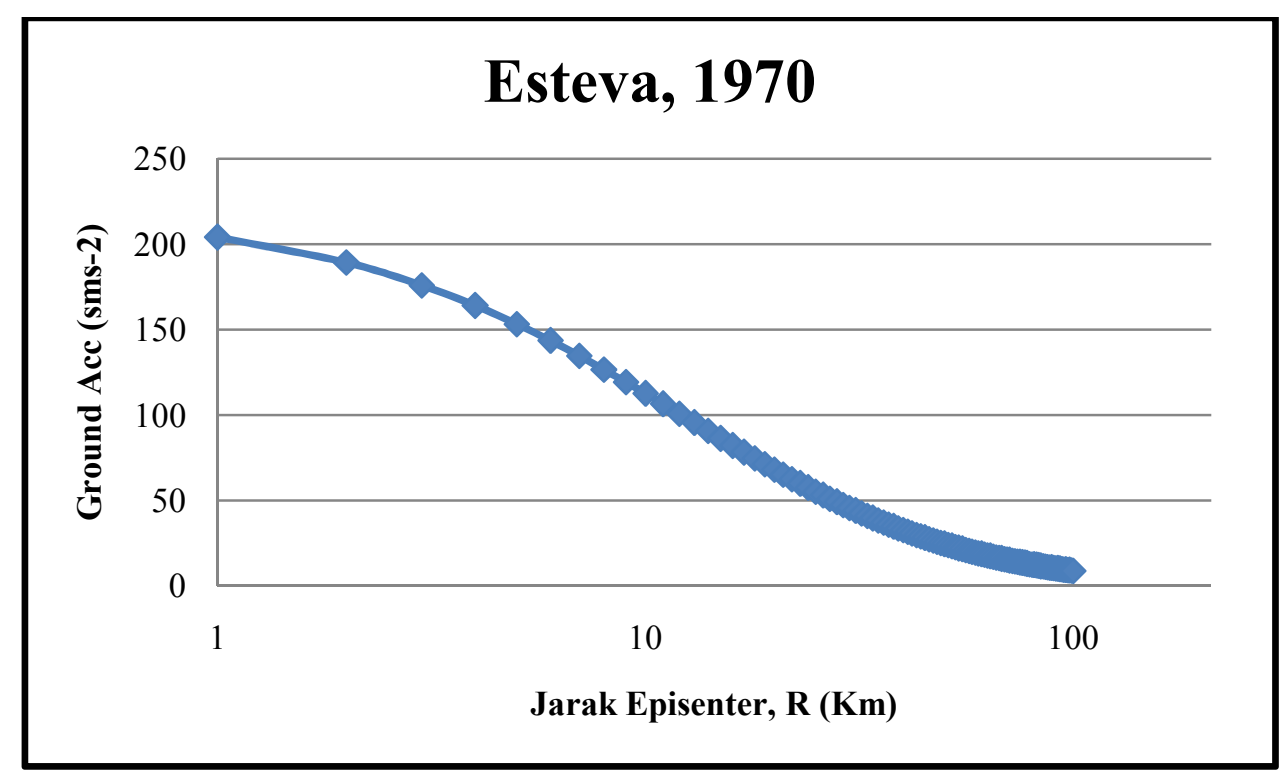

Gambar 1 Kurva Hazard dengan Atenuasi Esteva (1970)

\section{Fungsi Atenuasi Hou \& Hu (1991)}

Perhitungan dilakukan seperti fungsi atenuasi sebelumnya. Namun memenuhi fungsi persamaan berikut:

$\log \mathrm{Y}=0,894+0,563 \cdot \mathrm{M}-1,523 \log \left(\mathrm{R}+0,231 . \mathrm{e}^{0,626 \cdot \mathrm{M}}\right)$

Dengan nilai e $=2,71828183$

$$
\begin{aligned}
& \mathrm{M}=5,9 \mathrm{SR} \\
& \mathrm{R}=1-100 \mathrm{Km}
\end{aligned}
$$

Tabel 3 Hitungan Persamaan Atenuasi Hou \& Hu (1991)

\begin{tabular}{|c|c|c|c|c|c|c|c|}
\hline \multicolumn{3}{|c|}{ Hou \& Hu, 1991 } & \multicolumn{5}{|c|}{ R } \\
\hline $\mathbf{1}$ & $\mathbf{2}$ & $\mathbf{3}$ & $\mathbf{4}$ & $\mathbf{1}$ & $\mathbf{2}$ & $\mathbf{3}$ & $\mathbf{4}$ \\
\hline 2387,424138 & 99,73329263 & 38,26611651 & 21,35023341 & 1 & 26 & 51 & 76 \\
1635,784274 & 94,63858976 & 37,20286465 & 20,94281925 & 2 & 27 & 52 & 77 \\
1208,612851 & 89,96101284 & 36,18767649 & 20,54812476 & 3 & 28 & 53 & 78 \\
939,0478383 & 85,65437453 & 35,21757164 & 20,16560224 & 4 & 29 & 54 & 79 \\
756,2992825 & 81,67885308 & 34,28980285 & 19,79473385 & 5 & 30 & 55 & 80 \\
625,7631714 & 77,99995 & 33,40183416 & 19,43502972 & 6 & 31 & 56 & 81 \\
528,7365985 & 74,58765872 & 32,55132134 & 19,08602611 & 7 & 32 & 57 & 82 \\
454,3211982 & 71,41574684 & 31,73609455 & 18,74728372 & 8 & 33 & 58 & 83 \\
395,7833422 & 68,46121429 & 30,95414268 & 18,41838612 & 9 & 34 & 59 & 84 \\
348,7626037 & 65,70380955 & 30,20359947 & 18,09893834 & 10 & 35 & 60 & 85 \\
310,3244634 & 63,1256408 & 29,48273091 & 17,78856554 & 11 & 36 & 61 & 86 \\
278,4294229 & 60,71084866 & 28,789924 & 17,48691173 & 12 & 37 & 62 & 87 \\
251,6207832 & 58,4453312 & 28,1236766 & 17,19363868 & 13 & 38 & 63 & 88 \\
228,8333992 & 56,31651176 & 27,48258825 & 16,90842478 & 14 & 39 & 64 & 89 \\
209,2723877 & 54,31314227 & 26,8653519 & 16,63096415 & 15 & 40 & 65 & 90 \\
192,3338497 & 52,42513578 & 26,27074641 & 16,3609656 & 16 & 41 & 66 & 91
\end{tabular}




\begin{tabular}{|c|c|c|c|c|c|c|c|}
177,5516701 & 50,64342332 & 25,69762976 & 16,09815187 & 17 & 42 & 67 & 92 \\
164,560978 & 48,95983125 & 25,14493285 & 15,84225877 & 18 & 43 & 68 & 93 \\
153,0725262 & 47,36697559 & 24,61165395 & 15,59303447 & 19 & 44 & 69 & 94 \\
142,8543923 & 45,85817084 & 24,09685352 & 15,35023876 & 20 & 45 & 70 & 95 \\
133,718689 & 44,42735094 & 23,59964961 & 15,11364244 & 21 & 46 & 71 & 96 \\
125,5117669 & 43,06900061 & 23,1192136 & 14,8830267 & 22 & 47 & 72 & 97 \\
118,1068912 & 41,77809547 & 22,65476627 & 14,65818254 & 23 & 48 & 73 & 98 \\
111,3987003 & 40,55004972 & 22,20557432 & 14,43891025 & 24 & 49 & 74 & 99 \\
105,2989622 & 39,38067028 & 21,77094705 & 14,2250189 & 25 & 50 & 75 & 100 \\
\hline
\end{tabular}

Berdasarkan persamaan tersebut maka diperoleh kurva hazard seperti yang terlihat pada Gambar 2 berikut:

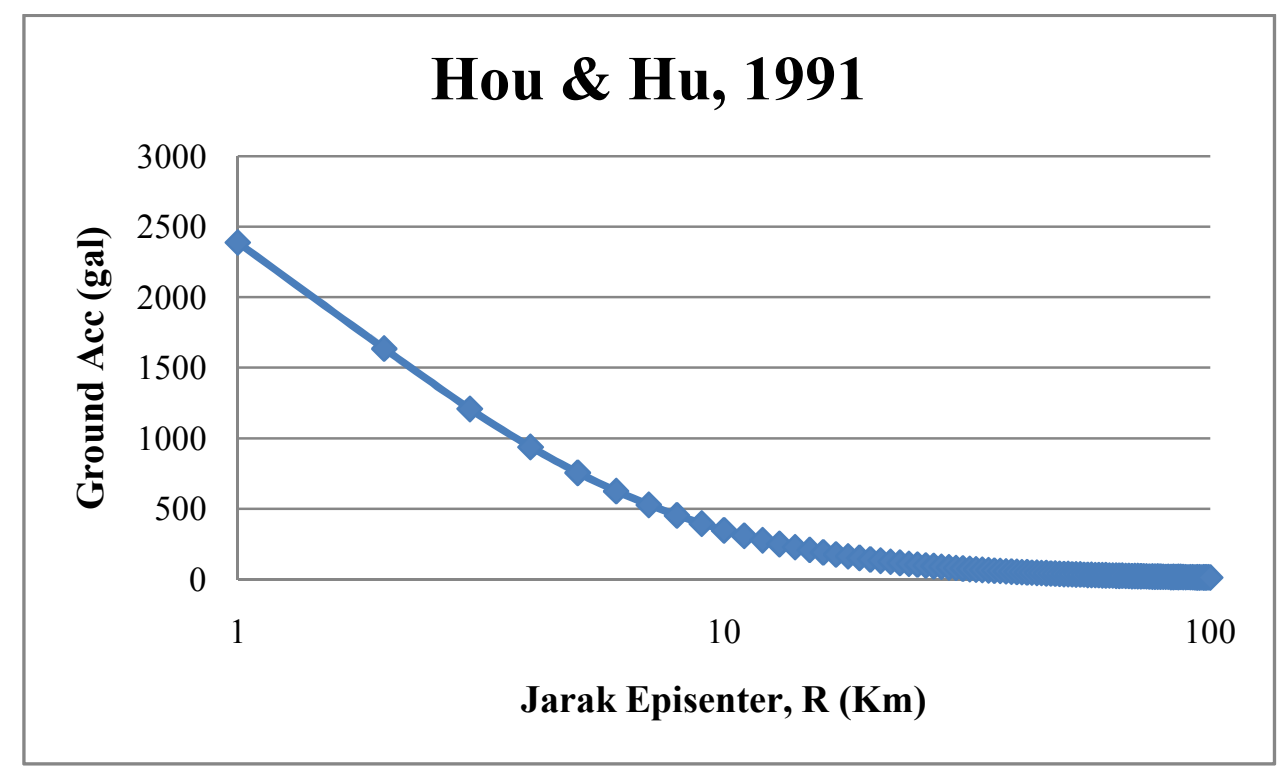

Gambar 2 Kurva Hazard dengan Atenuasi Hou \& Hu (1991)

\section{Fungsi Atenuasi Ambraseys (1995)}

Perhitungan dilakukan seperti fungsi atenuasi sebelumnya. Namun memenuhi fungsi persamaan berikut:

$\log \mathrm{Y}=-1,09+0,238 . \mathrm{Ms}-0,0005 . \mathrm{r}-\log \mathrm{r}, \mathrm{r}^{2}=\mathrm{R}^{2}+6^{2}$

Dengan nilai e $=2,71828183$

$$
\begin{aligned}
& \mathrm{M}=5,9 \mathrm{SR} \\
& \mathrm{R}=1-100 \mathrm{Km}
\end{aligned}
$$

Tabel 4 Hitungan Persamaan Atenuasi Ambraseys (1995)

\begin{tabular}{|c|c|c|c|c|c|c|c|}
\hline \multicolumn{4}{|c|}{ Ambraseys, 1995 } & \multicolumn{4}{|c|}{ R } \\
\hline $\mathbf{1}$ & $\mathbf{2}$ & $\mathbf{3}$ & $\mathbf{4}$ & $\mathbf{1}$ & $\mathbf{2}$ & $\mathbf{3}$ & $\mathbf{4}$ \\
\hline 0,33655632 & 0,07492355 & 0,03784156 & 0,02476960 & 1 & 26 & 51 & 76 \\
0,32359941 & 0,07220046 & 0,03708107 & 0,02442182 & 2 & 27 & 52 & 77 \\
0,30495773 & 0,06965868 & 0,03634876 & 0,02408292 & 3 & 28 & 53 & 78
\end{tabular}




\begin{tabular}{l|l|l|l|l|l|l|l|}
0,28352593 & 0,06728110 & 0,03564312 & 0,02375255 & 4 & 29 & 54 & 79 \\
0,26159531 & 0,06505265 & 0,03496272 & 0,02343040 & 5 & 30 & 55 & 80 \\
0,24059750 & 0,06296001 & 0,03430624 & 0,02311617 & 6 & 31 & 56 & 81 \\
0,22124872 & 0,06099135 & 0,03367246 & 0,02280957 & 7 & 32 & 57 & 82 \\
0,20379804 & 0,05913617 & 0,03306022 & 0,02251033 & 8 & 33 & 58 & 83 \\
0,18823429 & 0,05738511 & 0,03246846 & 0,02221819 & 9 & 34 & 59 & 84 \\
0,17442133 & 0,05572976 & 0,03189616 & 0,02193290 & 10 & 35 & 60 & 85 \\
0,16217548 & 0,05416261 & 0,03134240 & 0,02165422 & 11 & 36 & 61 & 86 \\
0,15130579 & 0,05267690 & 0,03080628 & 0,02138194 & 12 & 37 & 62 & 87 \\
0,14163290 & 0,05126651 & 0,03028700 & 0,02111582 & 13 & 38 & 63 & 88 \\
0,13299651 & 0,04992594 & 0,02978376 & 0,02085568 & 14 & 39 & 64 & 89 \\
0,12525700 & 0,04865020 & 0,02929585 & 0,02060130 & 15 & 40 & 65 & 90 \\
0,11829450 & 0,04743474 & 0,02882257 & 0,02035250 & 16 & 41 & 66 & 91 \\
0,11200681 & 0,04627544 & 0,02836329 & 0,02010911 & 17 & 42 & 67 & 92 \\
0,10630701 & 0,04516854 & 0,02791740 & 0,01987094 & 18 & 43 & 68 & 93 \\
0,10112122 & 0,04411060 & 0,02748432 & 0,01963783 & 19 & 44 & 69 & 94 \\
0,09638655 & 0,04309847 & 0,02706351 & 0,01940963 & 20 & 45 & 70 & 95 \\
0,09204933 & 0,04212928 & 0,02665446 & 0,01918618 & 21 & 46 & 71 & 96 \\
0,08806363 & 0,04120037 & 0,02625669 & 0,01896734 & 22 & 47 & 72 & 97 \\
0,08438999 & 0,04030930 & 0,02586974 & 0,01875296 & 23 & 48 & 73 & 98 \\
0,08099440 & 0,03945384 & 0,02549318 & 0,01854291 & 24 & 49 & 74 & 99 \\
0,07784744 & 0,03863190 & 0,02512659 & 0,01833706 & 25 & 50 & 75 & 100 \\
\hline
\end{tabular}

Berdasarkan persamaan tersebut maka diperoleh kurva hazard seperti yang terlihat pada Gambar 3 berikut:

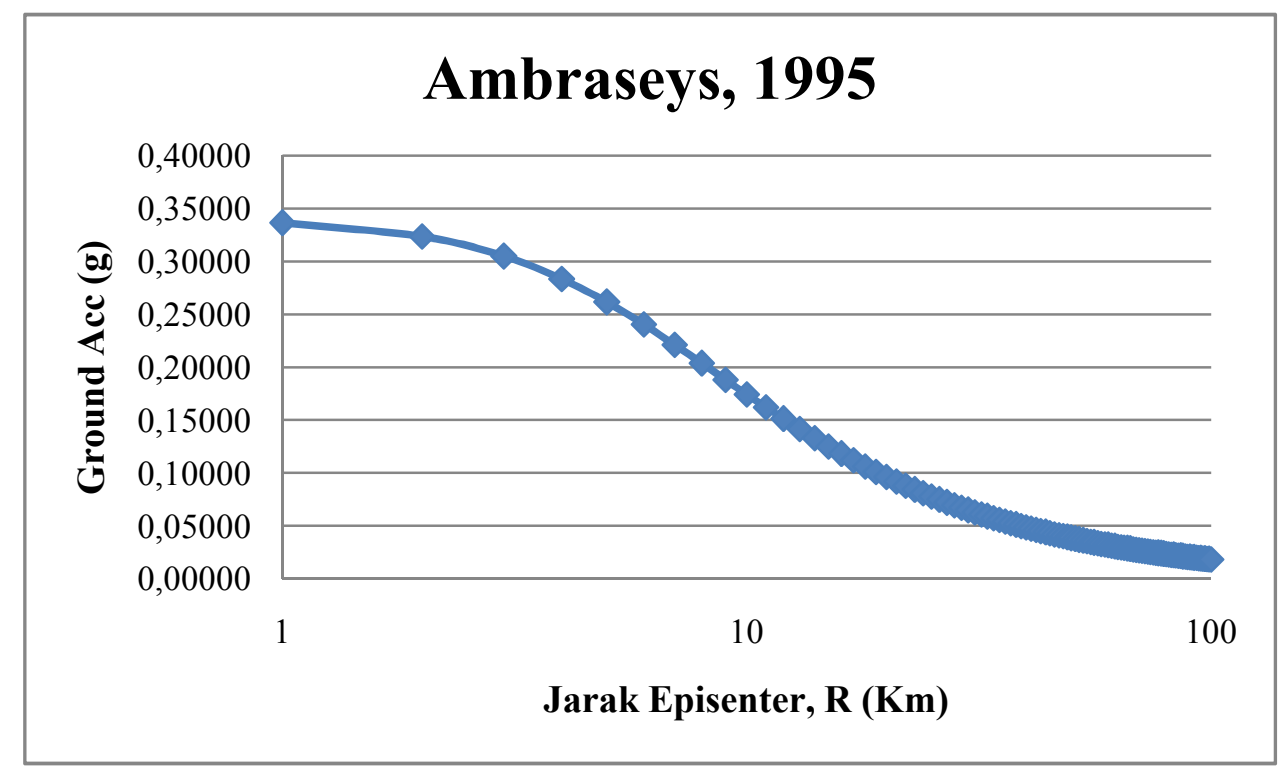

Gambar 3 Kurva Hazard dengan Atenuasi Ambraseys (1995) 


\section{Fungsi Atenuasi Crouse - Mc Guirre (1996)}

Perhitungan dilakukan seperti fungsi atenuasi sebelumnya. Namun memenuhi fungsi persamaan berikut:

$\operatorname{Ln} \mathrm{Y}=-2,3427+1,091 \cdot \mathrm{M}-1,7516 \operatorname{Ln}\left(\mathrm{R}+0,413 \cdot \mathrm{e}^{(0,6232 \cdot \mathrm{M})}\right)+0,0875 \cdot \mathrm{F}$

Dengan nilai e $=2,71828183$

$$
\begin{aligned}
& M=5,9 S R \\
& R=1-100 \mathrm{Km} \\
& F=0
\end{aligned}
$$

\begin{tabular}{|c|c|c|c|c|c|c|c|}
\hline \multicolumn{4}{|c|}{ Crouse-McGuirre, 1996 (F=0) } & \multicolumn{4}{|c|}{$\mathbf{R}$} \\
\hline 1 & 2 & 3 & 4 & 1 & 2 & 3 & 4 \\
\hline 0,407673 & 0,085265 & 0,037816 & 0,021749 & 1 & 26 & 51 & 76 \\
\hline 0,369504 & 0,081848 & 0,036852 & 0,021343 & 2 & 27 & 52 & 77 \\
\hline 0,336663 & 0,078641 & 0,035925 & 0,020948 & 3 & 28 & 53 & 78 \\
\hline 0,308186 & 0,075627 & 0,035035 & 0,020565 & 4 & 29 & 54 & 79 \\
\hline 0,283317 & 0,072790 & 0,034179 & 0,020192 & 5 & 30 & 55 & 80 \\
\hline 0,261462 & 0,070117 & 0,033356 & 0,019830 & 6 & 31 & 56 & 81 \\
\hline 0,242143 & 0,067596 & 0,032563 & 0,019478 & 7 & 32 & 57 & 82 \\
\hline 0,224976 & 0,065213 & 0,031800 & 0,019136 & 8 & 33 & 58 & 83 \\
\hline 0,209646 & 0,062961 & 0,031064 & 0,018803 & 9 & 34 & 59 & 84 \\
\hline 0,195895 & 0,060828 & 0,030355 & 0,018479 & 10 & 35 & 60 & 85 \\
\hline 0,183510 & 0,058806 & 0,029670 & 0,018164 & 11 & 36 & 61 & 86 \\
\hline 0,172312 & 0,056888 & 0,029010 & 0,017857 & 12 & 37 & 62 & 87 \\
\hline 0,162152 & 0,055066 & 0,028372 & 0,017559 & 13 & 38 & 63 & 88 \\
\hline 0,152901 & 0,053335 & 0,027757 & 0,017268 & 14 & 39 & 64 & 89 \\
\hline 0,144454 & 0,051687 & 0,027161 & 0,016984 & 15 & 40 & 65 & 90 \\
\hline 0,136717 & 0,050118 & 0,026586 & 0,016708 & 16 & 41 & 66 & 91 \\
\hline 0,129612 & 0,048623 & 0,026030 & 0,016439 & 17 & 42 & 67 & 92 \\
\hline 0,123070 & 0,047196 & 0,025492 & 0,016176 & 18 & 43 & 68 & 93 \\
\hline 0,117032 & 0,045834 & 0,024970 & 0,015920 & 19 & 44 & 69 & 94 \\
\hline 0,111447 & 0,044533 & 0,024466 & 0,015671 & 20 & 45 & 70 & 95 \\
\hline 0,106270 & 0,043289 & 0,023977 & 0,015427 & 21 & 46 & 71 & 96 \\
\hline 0,101460 & 0,042099 & 0,023504 & 0,015189 & 22 & 47 & 72 & 97 \\
\hline 0,096984 & 0,040959 & 0,023045 & 0,014957 & 23 & 48 & 73 & 98 \\
\hline 0,092810 & 0,039867 & 0,022600 & 0,014731 & 24 & 49 & 74 & 99 \\
\hline 0,088912 & 0,038820 & 0,022168 & 0,014510 & 25 & 50 & 75 & 100 \\
\hline
\end{tabular}

Tabel 5 Hitungan Persamaan Atenuasi Crouse - Mc Guirre (1996)

\begin{tabular}{|c|c|c|c|c|c|c|c|}
\hline \multicolumn{4}{|c|}{ Crouse-McGuirre, 1996 (F=1) } & \multicolumn{4}{c|}{ R } \\
\hline $\mathbf{1}$ & $\mathbf{2}$ & $\mathbf{3}$ & $\mathbf{4}$ & $\mathbf{1}$ & $\mathbf{2}$ & $\mathbf{3}$ & $\mathbf{4}$ \\
\hline 0,4444952 & 0,093062 & 0,041274 & 0,023738 & 1 & 26 & 51 & 76 \\
0,403292 & 0,089332 & 0,040221 & 0,023294 & 2 & 27 & 52 & 77 \\
0,367449 & 0,085832 & 0,039211 & 0,022864 & 3 & 28 & 53 & 78 \\
0,336367 & 0,082542 & 0,038239 & 0,022445 & 4 & 29 & 54 & 79
\end{tabular}




\begin{tabular}{|l|l|l|l|l|l|l|l|}
0,309224 & 0,079446 & 0,037305 & 0,022038 & 5 & 30 & 55 & 80 \\
0,285371 & 0,076529 & 0,036406 & 0,021643 & 6 & 31 & 56 & 81 \\
0,264285 & 0,073777 & 0,035541 & 0,021259 & 7 & 32 & 57 & 82 \\
0,245548 & 0,071177 & 0,034708 & 0,020886 & 8 & 33 & 58 & 83 \\
0,228816 & 0,068718 & 0,033904 & 0,020522 & 9 & 34 & 59 & 84 \\
0,213808 & 0,066390 & 0,033130 & 0,020169 & 10 & 35 & 60 & 85 \\
0,200291 & 0,064183 & 0,032383 & 0,019825 & 11 & 36 & 61 & 86 \\
0,188069 & 0,062090 & 0,031663 & 0,019490 & 12 & 37 & 62 & 87 \\
0,176979 & 0,060102 & 0,030967 & 0,019164 & 13 & 38 & 63 & 88 \\
0,166883 & 0,058212 & 0,030295 & 0,018847 & 14 & 39 & 64 & 89 \\
0,157663 & 0,056413 & 0,029645 & 0,018537 & 15 & 40 & 65 & 90 \\
0,149219 & 0,054701 & 0,029017 & 0,018236 & 16 & 41 & 66 & 91 \\
0,141464 & 0,053069 & 0,028410 & 0,017942 & 17 & 42 & 67 & 92 \\
0,134324 & 0,051512 & 0,027823 & 0,017655 & 18 & 43 & 68 & 93 \\
0,127734 & 0,050025 & 0,027254 & 0,017376 & 19 & 44 & 69 & 94 \\
0,121638 & 0,048605 & 0,026703 & 0,017104 & 20 & 45 & 70 & 95 \\
0,115987 & 0,047247 & 0,026170 & 0,016838 & 21 & 46 & 71 & 96 \\
0,110738 & 0,045948 & 0,025653 & 0,016578 & 22 & 47 & 72 & 97 \\
0,105852 & 0,044704 & 0,025152 & 0,016325 & 23 & 48 & 73 & 98 \\
0,101297 & 0,043512 & 0,024666 & 0,016078 & 24 & 49 & 74 & 99 \\
0,097043 & 0,042370 & 0,024195 & 0,015837 & 25 & 50 & 75 & 100 \\
\hline
\end{tabular}

Berdasarkan persamaan tersebut maka diperoleh kurva hazard seperti yang terlihat pada Gambar 4 berikut:

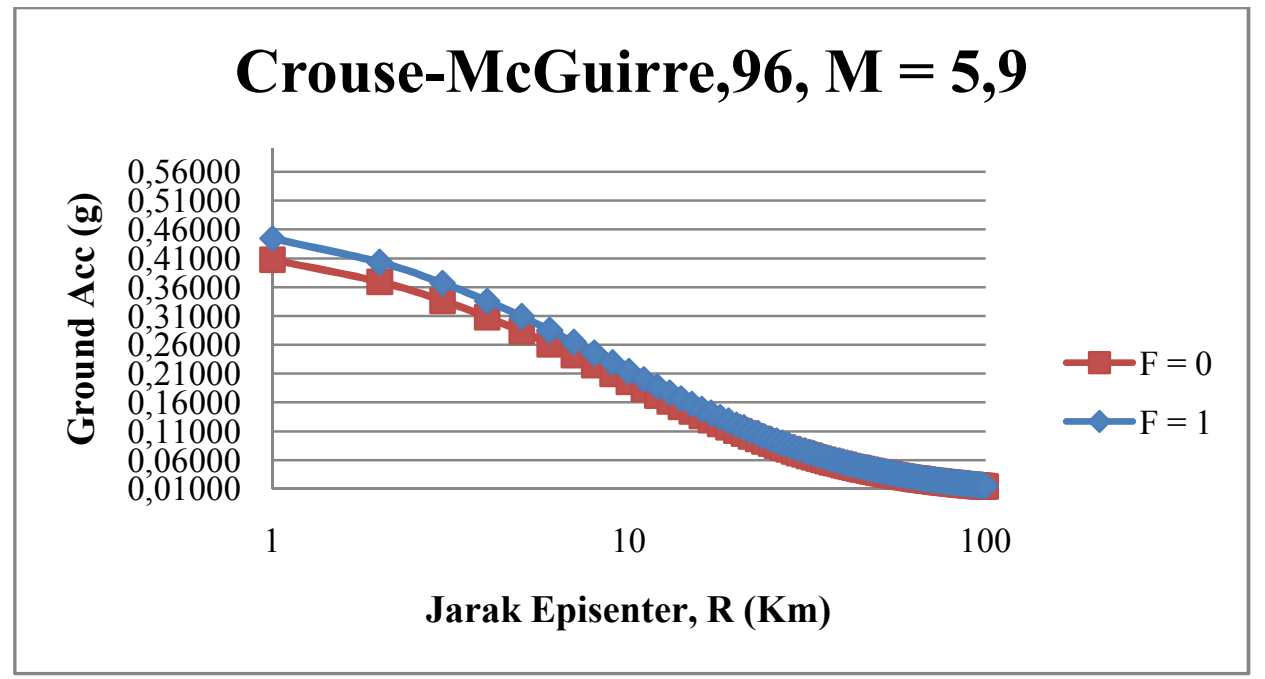

Gambar 4 Kurva Hazard dengan Atenuasi Crouse-McGuirre (1996), F = 0 dan F = 1 


\section{Perbandingan Fungsi-Fungsi Atenuasi}

Setelah melakukan analisis dengan menggunakan fungsi Atenuasi Esteva (1970), fungsi Atenuasi Hou \& Hu (1991), fungsi Atenuasi Ambraseys (1995) dan Fungsi Atenuasi Crouse-Mc Guirre (1996) di atas maka diperoleh hasil kurva hazard seperti yang tersaji pada Gambar 6 berikut ini.

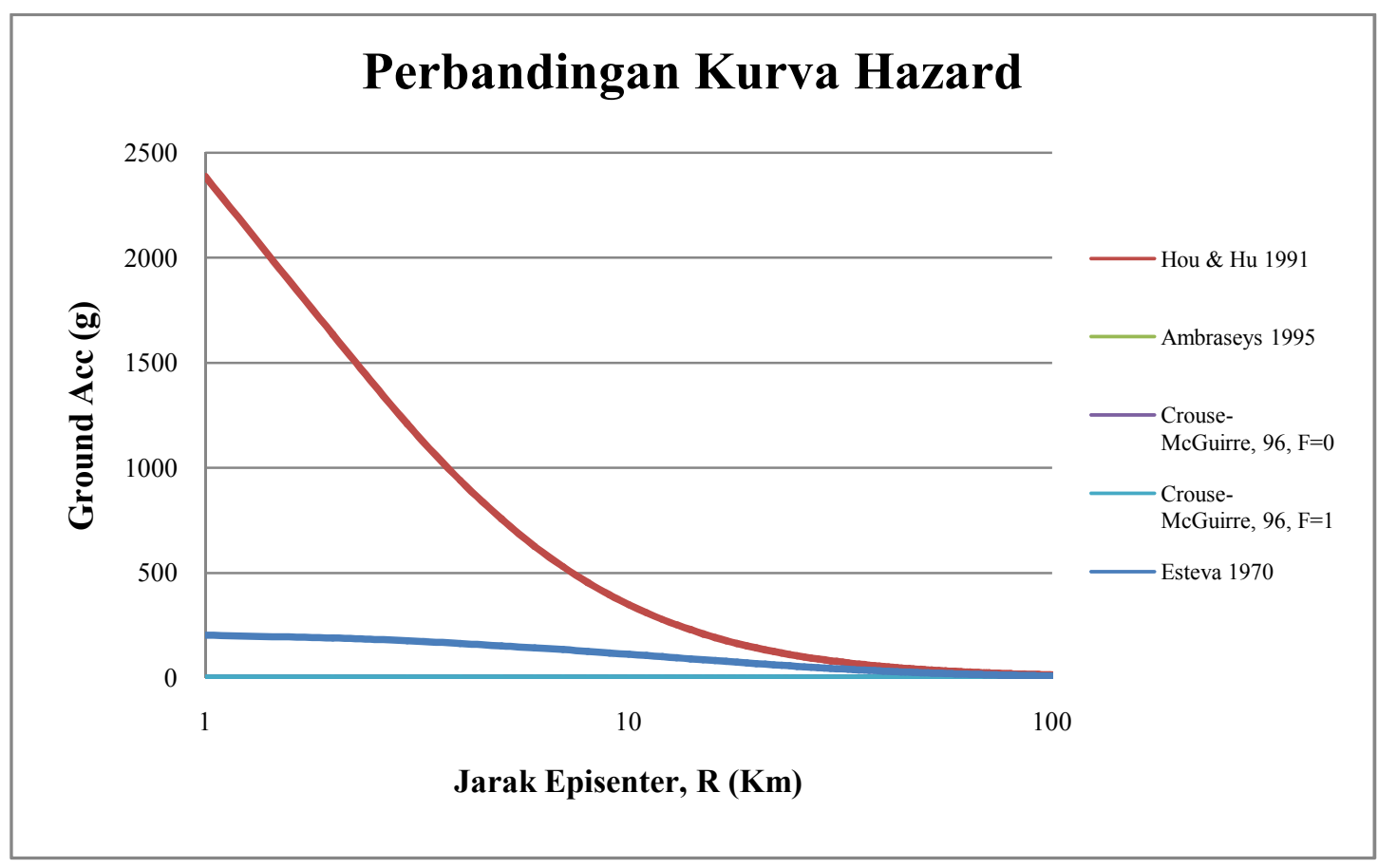

Gambar 6 Perbandingan Kurva Hazard dengan Beberapa Fungsi Atenuasi

Berdasarkan hasil Gambar 6 di atas menunjukkan besarnya nilai percepatan tanah (ground acceleration) akan semakin mengecil pada jarak atau radius yang semakin jauh. Hasil analisa juga menunjukkan bahwa kurva hazard menunjukkan nilai terbesar pada saat menggunakan fungsi atenuasi Hou \& Hu 199 sedangkan nilai terkecil pada kurva hazard terjadi pada saat menggunakan fungsi atenuasi Crouse-McGuirre (1996), $\mathrm{F}=0$. Kurva hazard ini dapat digunakan dalam menentukan besarnya percepatan tanah di daerah kabupaten tambrauw. Hal ini juga dapat dianggap sebagai langkah mitigasi. Upaya mitigasi perlu dilakukan untuk mengidentifikasi bencana yang akan terjadi dikemudian hari dengan mengambil langkah antisipasi. Hal ini dilakukan dalam rangka untuk mengurangi resiko yang ditimbulkan sehingga tingkat kerugian dan korban yang berjatuhan dapat diminimalisir.

\section{Kesimpulan}

Berdasarkan hasil analisa di atas maka diperoleh beberapa kesimpulan sebagai berikut:

1. Besarnya nilai percepatan tanah (ground acceleration) akan semakin mengecil pada jarak atau radius yang semakin jauh.

2. Analisis kurva hazard pada daerah Kabupaten Tambrauw akibat pergeseran lempeng akan menunjukkan nilai terbesar pada saat menggunakan fungsi atenuasi Hou \& Hu 1991. 
3. Analisis kurva hazard pada daerah Kabupaten Tambrauw akibat pergeseran lempeng akan menunjukkan nilai terkecil pada saat menggunakan fungsi atenuasi Crouse-McGuirre (1996), $\mathrm{F}=0$.

\section{Daftar Pustaka}

1. Saputro, I. T. (2018, June 6). ANALISIS PERBANDINGAN KURVA HAZARD PADA KOTA BANDA ACEH DENGAN SUMBER GEMPA SESAR SEULIMEUM DAN MENGGUNAKAN BEBERAPA FUNGSI ATENUASI. https://doi.org/10.17605/OSF.IO/UVP2Y

2. Widodo, 2012, Seismologi Teknik \& Rekayasa Kegempaan, Pustaka Pelajar, Yogyakarta

3. Widodo, Atenuasi Gerakan Tanah dan Atenuasi Intensitas Gempa, Universitas Islam Indonesia, Yogyakarta

4. Sofyan Hery, Kabupaten Tambrauw 